\title{
KOMPETENSI SPIRITUALITAS MAHASISWA
}

\author{
Yuni Novitasari ${ }^{1}$
}

\begin{abstract}
This study aims to present spirituality student competency profiles, which can provide a view of cultural competence on the part of students or the spirituality of the people of Indonesia. The method used is survey. Subjects consisted of 50 students on the course for guidance and counseling. Most categories of student spirituality competency is moderate, with highs in the affective aspects, aspects of cognitive and psychomotor lowest at. Therefore, the development of spirituality on student competence becomes important. Especially the development of the cognitive and psychomotor aspects. Competence spirituality is a potential in human beings that can evolve positively. As the results of research and studies mention that spirituality has contributed to mental health, positive moral behavior, professionalism, physical health, as well as character development. Character development is part of a very important educational mission. Moreover, the students as the next generation of nation-building, it is necessary formation of strong character. Belief in God and positive moral behavior is one of the main characters to be achieved in the national education goals. Spirituality can be a major potential in the development of the character.
\end{abstract}

Keywords: Cultural, Competence, Spirituality, Students, Guidance and Counseling.

JOMSIGN: Journal of Multicultural Studies in Guidance and Counseling

Website : http://ejournal.upi.edu/index.php/JOMSIGN

Permalink: http://ejournal.upi.edu/index.php/JOMSIGN/article/view/6051

How to cite (APA): Novitasari, Y. (2017). Kompetensi spiritual mahasiswa. JOMSIGN: Journal of Multicultural Studies in Guidance and Counseling, 1(1), 45-70.

This is an open access article distributed under the terms of the Creative Commons Attribution 4.0 International License, which permits unrestricted use, distribution, and reproduction in any medium, provided the original work is properly cited.

\section{PENDAHULUAN}

Perkembangan ilmu pengetahuan psikologi saat ini tengah berkembang mengkaji tentang fenomena pengalaman transpersonal atau spiritual manusia. Ditemukan bahwa manusia memiliki potensi spiritualitas yang sejatinya bisa dimanfaatkan menjadi kekuatan untuk kesembuhan psikologis dan pengembangan pribadi. Beberapa hasil penelitian dan kajian menunjukan bahwa spiritualitas berkontribusi positif terhadap kesehatan mental, perilaku moral, dan juga kesehatan fisik Tuhan (Richards \& Bergin, 2000; 2005;

\footnotetext{
${ }^{1}$ Universitas Muhammadiyah Metro, Indonesia; yunibkumm@gmail.com.
} 
Anderson \& Reese, 1999). Spiritualitas juga dibuktikan memiliki kontribusi negatif pada gangguan jiwa. Munculnya pemahaman tentang manfaat potensi spiritualitas pada diri manusia, mendorong banyak kajian dan penelitian yang memanfaatkan potensi spiritualitas dalam psikologi, bimbingan dan konseling (Miller, 2013; Lines, 2006). Dengan demikian, perkembangan kajian psikologi modern, hakikat manusia tidak lagi sebatas kebutuhan jasmani dan rohani dasar manusia, tetapi juga mengkaji fenomena spiritual dalam jiwa manusia (Miller, 2013; Lines, 2006; Nickles, 2011; Hidayat, 2016, p. 4; Novitasari \& Nur, 2017, p. 58).

Ditambah lagi, telah banyak kajian dan hasil penelitian tentang pengembangan spiritualitas dalam bidang ilmu-ilmu lainnya. Ini artinya spiritualitas sebagai suatu fitrah bagian dari diri manusia yang sejatinya memiliki potensi besar untuk dimanfaatkan. Terkait dengan ini, dalam dunia keilmuan bimbingan dan konseling tengah berkembang studi tentang pengintegrasian spiritualitas dalam praktik bimbingan dan konseling. Sebagaimana di Amerika, badan akreditasi untuk para calon konselor yakni Council for Accreditation of Counseling and Related Educational Programs (CARCEP) telah menetapkan persyaratan kompetensi spiritualitas bagi konselor. Mengingat perkembangan studi tentang potensi spiritual, tampaknya menjadi suatu kebutuhan untuk pengembangan lebih lanjut di Indonesia.

Secara budaya, Ahimsa-Putra (2011) mengatakan bahwa masyarakat Indonesia memiliki tingkat spiritualitas yang tinggi dilihat dari sila pertama pancasila sebagai pedoman bangsa, yakni ke-Tuhanan yang maha esa. Disamping itu, Ahimsa juga menyebutkan sebagian masyarakat Indonesia yang masih banyak percaya pada hal-hal ghaib, melakukan ziarah kubur untuk memperoleh pertolongan, melakukan tirakat, dan sebagainya. Menurut Ahimsa ini merupakan salah satu tanda nilai spiritualitas yang tergolong masih tinggi pada masyarakat Indonesia.

Spiritualitas merupakan salah satu atribut psikologi seseorang. Spiritualitas dipandang sebagai pengalaman kesadaran psikologis seseorang yang bisa menjadi potensi besar bagi penyembuhan psikologis dan pengembangan pribadi (Cunningham, 2011; Shorrock, 2008). Spiritual merupakan pengalaman kesadaran individu dalam upaya menghormati keberadaan alam sejagat raya, yang dikaitkan dengan kekuatan tertinggi dalam kehidupan ini (transenden), seperti Tuhan, keabadian, puncak kebenaran tertinggi, nilai-nilai luhur, sesuatu yang bermakna, sehingga dengannya sering menginspirasi perasaan 
keberdayaan, harapan, kerendahan hati, dan takjub (Eaude, 2008; Tisdell, 2003; Wright, 2000). Spiritualitas ialah upaya perhatian individu terhadap makna dan tujuan hidup dalam konteks hubungan dengan alam semesta, dan atau Tuhan (Steiner, 1991; Sperry \& Giblin; 1996, Miller \& Thoresen, 1999, George et al; 2000, Webb, Toussaint, \& Dula, 2014). Richards dan Bergin (2005) juga menyatakan karakteristik inti dari orang spiritual ialah mereka menikmati penuh kasih dan kedekatan yang tulus, dan keharmonisan. Dapat disimpulkan bahwa spiritualitas ialah suatu pengalaman kesadaran seseorang dalam menemukan makna terhadap suatu kejadian dalam kehidupannya, yang menyertakan penghayatan dan penghormatan terhadap keberadaan alam sejagat raya dan kekuatan tertinggi dalam kehidupan ini (seperti Tuhan, keabadian, puncak kebenaran tertinggi, nilai-nilai luhur), sehingga sering kali menginspirasi rasa keberdayaan, harapan, rendah hati, takjub, kasih sayang, ketulusan, dan keharmonisan hidup.

Spiritualitas sering kali dikaitkan dengan religiusitas atau agama, namun sejatinya keduanya berbeda (Fox, 1999; Thoreau \& Ingman, 2004; Denton \& Ashton, 2004; Palmer, 2004). Religiusitas cenderung bersifat ritualistik, memiliki institusi, ada sistem organisasi dan jabatan, memiliki doktrin dan batas-batas tertentu sesuai ajaran religi dan instruksi rahib/guru religi, berpotensi menimbulkan pengejaran duniawi atau sekuler (Miller \& Thoresen, 1999; Grof, 2000). Sementara spiritual lebih bersifat lebih luas dari religiusitas, holistik, sulit menyebutkan batas-batasnya, tidak menekankan pada ritualistik, tetapi lebih menekankan pada kebermaknaan, spiritualitas tidak bergantung pada agama, spiritualitas terbebas dari potensi pengejaran duniawi (Hay \& Nye, 1998; Miller \& Thoresen, 1999; Grof, 2000). Meski demikian, puncak hakikat spiritualitas dan religiusitas ialah pencarian sesuatu yang paling hakiki (Hay, Reich, \& Utsch, 2006). Terkait hal ini, Wintz \& Copper (2001) juga menyebutkan bahwa spiritual itu: dapat dimiliki oleh orang yang beragama maupun yang tidak beragama; Mengekspresikan sumber makna, keyakinan keterhubungan dan haapan; Keyakinan, nilai dan situasi bermain penting dalam pembentukan spiritualitas seseorang; dan Spiritualitas masing-masing orang ialah penting. Dengan demikian, spiritualitas merupakan suatu atribut psikologis tersendiri dalam diri seseorang, yang memungkinkan bisa berkembang.

Spiritualitas merupakan salah satu atribut psikologis yang dimiliki manusia, meski masing-masing pengalaman individu memiliki tingkat yang berbeda- 
beda. Maslow (1962) mengatakan bahwa kehidupan spiritual (kontemplatif, religius, filosopi, atau nilai kehidupan) merupakan bagian penting pada esensi manusia. Dalam studinya fungsi optimal manusia pada hirarki tertinggi dilabelkan pada aktualisasi transenden. Berdasarkan pendapat Maslow tersebut, dapat dipahami jika spiritualitas merupakan suatu potensi yang bisa menjadi besar dan menunjukan sifat-sifat sejatinya manusia.

Sebagaimana pengembangan kepribadian manusia, spiritualitas pada individu juga berkembang sesuai potensi dan pengalaman individu itu sendiri. Meski demikian, spiritualitas bisa terus berkembang. Yusuf dan Nurihsan (2008) menyebutkan kepribadian individu dipengaruhi oleh berbagai faktor diantaranya faktor hereditas (meliputi bentuk tubuh, cairan tubuh, dan sifat-sifat yang diturunkan oleh orangtua) dan lingkungan (meliputi keluarga, kebudayaan, sekolah). Terkait dengan spiritualitas, memungkinkan faktor hereditas dan lingkungan membentuk koping tersendiri pada diri individu, demikian juga dalam membentuk kekuatan spiritualitasnya. Beberapa situasi dan kejadian dapat dipahami sebagai fenomena lingkungan yang bisa mendukung perkembangan spiritualitas individu.

Wintz \& Cooper (2001) menyebutkan beberapa pemicu yang dapat menyebabkan fokus spiritual ataupun krisis dalam kehidupan seseorang mencakup; 1) Faktor fisik (seperti penyakit, kecelakaan, operasi, kurang tidur atau makanan, atau pengalaman melahirkan); 2) Pengalaman emosional atau transisi (kelahiran, membuat komitmen seperti hubungan yang signifikan, pernikahan, atau menjadi anggota dari sebuah komunitas iman, perubahan gaya hidup, bergerak, stres, atau kehilangan pekerjaan, pernikahan, persahabatan atau kematian); 3) Pengalaman dekat kematian (apakah itu sendiri atau yang orang yang dicintai); dan 5) Praktik Spiritual (meditasi, doa, ritual, atau kehadiran di gereja). Pengalaman-pengalamn tersebut memungkinkan untuk lebih mendorong rasa spiritualitas pada diri seseorang. Seringkali, jika didasari oleh pengalaman yang tidak mengenakan, spiritualitas menjadi jalan sebagai koping tersendiri.

Eaude (2004) mengutip pandangan Halstead dan Taylor bahwa nilai-nilai merupakan prinsip-prinsip dan keyakinan mendasar, keyakinan, cita-cita, dan standar yang memandu perilaku seseorang. Pengembangan spiritual erat dengan nilai-nilai karena diantaranya mencerminkan dan membentuk jenis seseorang. Dapat disimpulkan bahwa pengalaman seseorang yang mendukung tumbuh kembang spiritualitas dalam dirinya selalu disertai oleh nilai-nilai tertentu. 
Proses pengembangan spiritual bisa berlangsung terus secara bekelanjutan. Kwan (2011) mengatakan sebuah pengembangan pribadi tidak hanya terjadi sekali dan kemudian berhenti. Elder (1998) menyatakan pembangunan manusia berlangsung terus-menerus dalam jaringan hubungan bersama dengan perubahan waktu dan tempat. Elder (1998) memperjelas bahwa pengembangan diri individu terjadi melalui caranya dalam membuat pilihan dan mengambil tindakan dalam sepanjang rentang kehidupannya, dalam menghadapi kendala, peluang, dan keadaan sosial. Berdasarkan pendapat-pendapat tersebut, dapat ditarik benang merah bahwa perkembangan spiritualitas terkait dengan perkembangan nilai-nilai, dimana perkembangan nilai seseorang dipengaruhi oleh lingkungan (budaya, keluarga, masyarakat, sekolah), situasi dan kondisi, pengalaman emosional, keadaan fisik dan juga genetika. Genetika turut mempengaruhi pola emosional dan kepribadian tertentu.

Pengembangan diri kita tidak bisa lepas dari budaya. Budaya cukup banyak mempengaruhi cara hidup kita, baik berpikir, bersikap dan bertingkah laku. Menurut ilmu antropologi kebudayaan adalah keseluruhan sistem gagasan, tindakan dan hasil karya manusia dalam kehidupan masyarakat yang dijadikan milik diri manusia dengan belajar (Koentjaraningrat, 2009). Koentjaraningrat dalam bukunya menyebutkan budaya adalah daya dan budi yang berupa cipta, rasa, dan karsa. Sedangkan kebudayaan adalah hasil berupa cipta, rasa dan karsa. Selain itu, Kuentjoroningrat juga menyimpulkan bahwa hampir seluruh tindakan manusia adalah kebudayaan karena hanya sedikit tindakan manusia dalam kehidupan masyarakat yang tidak perlu dibiasakan dengan belajar, yaitu hanya beberapa tindakan naluri, beberapa reflek, beberapa tindakan akibat proses fisiologis, atau kelakuan membabi buta. Bahkan berbagai tindakan manusia yang merupakan kemampuan naluri yang terbawa dalam gen bersama kelahirannya (seperti makan, minum, berjalan dengan dua kaki), juga dirombak olehnya menjadi tindakan kebudayaan.

Belajar budaya adalah belajar atau berbagi pengetahuan, keyakinan, tradisi, adat istiadat, aturan, seni, sejarah, cerita rakyat dan lembaga dari sekelompok orang yang digunakan untuk menafsirkan pengalaman dan untuk menghasilkan suatu perilaku sosial (Wintz \& Cooper, 2001). Budaya itu organik dan dinamis, sehingga terus berubah, pengembangan budaya melibatkan anak-anak memahami dan belajar untuk mengubah dunia yang mereka huni (Eaude, 2008). Eagleton (2000) mengatakan budaya tidak hanya tentang dengan apa kita hidup. tetapi, juga, dalam ukuran besar, untuk apa kita hidup, kasih sayang, hubungan, 
memori, kekerabatan, tempat, masyarakat, pemenuhan emosional, kenikmatan intelektual, rasa kebermaknaan tertinggi. Oleh karena itu, dapat disimpulkan bahwa budaya adalah pola perilaku hidup seseorang atau kelompok tertentu sebagai hasil belajar, seperti mengenai pengetahuan, keyakinan, tradisi, adat istiadat, aturam, seni, sejarah, cerita rakyat, kekerabatan, tempat tinggal, pemenuhan emosional, intelektualitas, rasa kebermaknaan, hingga tujuan hidup. sementara itu, multikulturalisme merupakan paham yang menganut asas keragaman sosial-budaya yang dianut oleh suatu bangsa. Setiadi dan Kolip (2013) menyebutkan multikultur menekankan pada keanekaragaman kebudayaan, dalam kederajatan atau kesetaraan. Artinya tidak ada posisi superior dan inferior antar suku bangsa. Mengenai hal ini, Furnifall memberi batasan bahwa masyarakat multikultur adalah masyarakat yang terdiri dari atas dua atau lebih elemen yang hidup sendiri-sendiri tanpa ada pembauran satu sama lain dalam satu kesatuan politik.

Identitas budaya meliputi perbedaan berikut; objek simbol, bahasa, topik dan pola percakapan, intonasi suara, klue non verbal (gestur, ekspresi wajah, bahasa tubuh, dan ruang pribadi), konsep waktu (pesan, durasi, dan poin didalamnya), keluarga dan struktur kekerabatan (anggota dan otoritas), tradisi makan dan memasak, spiritual dan agama (Wintz \& Cooper, 2001). Setiap budaya sering memiliki ciri perbedaan tersendiri yang berbeda dengan budaya yang lain. Budaya dapat turut membentuk pola perilaku diri individu. Wintz \& Copper (2001) juga mengatakan bahwa budaya yang diusung sangat mempengaruhi sopan santun, keyakinan, nilai, dan tingkah laku.

Budaya terbentuk dalam jangka waktu yang lama. Zhou et al (2010) mengemukakan semua tradisi spiritual yang beragam mengakui fakta bahwa orang hidup dan bernapas dengan disposisi keyakinan lama (paradoks) yang berakar dalam ketakutan dan harapan, kecemasan dan kasih sayang, integrasi dan pemisahan. Dengan demikian, budaya terbentuk dari pola pikiran dan perasaan yang cenderung kolektif yang mendorong mereka untuk melakukan upaya sebagai pertahanan hidup. Oleh karena itu, budaya yang telah mengakar tidak mudah untuk berubah.

Meski demikian, budaya bisa berubah. Ofsted (2004) mengatakan pengembangan budaya adalah tentang memahami bahwa budaya selalu berubah dan bertahan dengan perubahan. Sebagaimana yang kita lihat saat ini, perubahan zaman menunjukan perubahan cara berkomunikasi. Seperti dahulu kita tidak mengenal handphone, kita sering berkomunikasi jarah jauh dengan 
surat saja. Sehingga kita membutuhkan waktu yang lama untuk memperoleh respon, tentu hal ini berbeda dengan zaman saat ini. Hal ini menunjukan adanya perubahan budaya komunikasi dalam perubahan zaman.

Sementara saat ini, perubahan begitu cepat seiring perkembangan ilmu pengetahuan dan komunikasi. Dapat dipahami jika kita bisa dengan mudah dan cepat mengetahui gambaran budaya orang dari negara lain. Perubahan pola perilaku yang begitu cepat ini turut mempengaruhi perilaku kita. Hal ini bisa berpotensi meninggalkan pola-pola budaya perilaku lama yang bersifat tradisional, terlebih apabila perilaku tradisional sudah tidak lagi menunjang untuk memenuhi kebutuhan hidup saat ini. Sehingga, sangat memungkinkan kita untuk mengadopsi pola-pola perilaku budaya baru yang mungkin berasal dari budaya orang lain. Contohnya, jika dahulu kita memasak nasi menggunakan dandang dan panci yang membutuhkan waktu cukup lama, saat ini kita cukup menggunakan magic jar.

Terkait dengan dunia pendidikan. Budaya sangat memiliki pengaruh besar dalam perkembangan perilaku peserta didik, oleh karena itu kita sebagai pendidik perlu memperhatikan perkembangan budaya peserta didik. Peserta didik yang kita hadapi memungkinkan berasal dari berbagai macam latar belakang baik suku, agama, ekonomi, stastus sosial dan lainnya. Perbedaan latar belakang tersebut mempengaruhi budaya perilaku individu peserta didik. Sementara itu, peserta didik dari berbagai macam latar belakang ini dituntut untuk bisa bersosialisasi satu sama lain. Oleh karena itu, kecakapan budaya perlu dimiliki dalam diri peserta didik. Jika tidak disertai kecakapan budaya ini, bisa menimbulkan konflik antar individu atau kelompok.

Eaude (2008) menyebutkan bahwa pengaruh perkembangan budaya dapat dilihat dari: 1) internal anak, seperti rendahnya tingkat harga diri atau keyakinan diri; dan 2) eksternal anak, seperti bullying dan rasisme atau lemahnya pemahaman mengenai permusuhan, tradisi budaya, baik di luar atau dalam sekolah. Dapat dipahami, poensi-potensi konfilk memungkinkan terjadi dalam pemahaman yang lemah tentang budaya. Dengan demikian, diperlukan upaya pengambangan budaya yang memadai bagi para peserta didik. Sebagaimana, Eaude juga mengatakan bahwa pengembangan budaya membantu anak-anak (peserta didik) untuk mengalami dan memahami: di mana mereka berada, dan persamaan dan perbedaan antara mereka dan orang lain; pengaruh yang membentuk budaya mereka sendiri dan orang lain; bagaimana memahami diri dan memahami pengalaman; bagaimana mereka aktif membuat dan mengubah 
cara agar mereka memahami dunia. Euade pun menjelaskan bahwa hal tersebut dapat dicapai melalui proses pembiasaan, refleksi dan perubahan, sehingga mencapai batas-batas diluar pengalaman sebelumnya dan belajar untuk bersikap kritis, dan melihat lebih luas dan dalam, kerangka keyakinan, nilai-nilai dan praktik di mana mereka tumbuh.

Oleh karena itu, pendidikan perlu memfasilitasi peserta didik agar memiliki keterampilan perilaku multibudaya yang baik atau memadai. Wintz \& Cooper (2001) menyebutkan beberapa keterampilan multibudaya yang perlu dimiliki diantaranya: 1) kemampuan komunikasi yang baik, 2) kemampuan untuk mengenali pertemuan lintas-budaya (kesadaran tinggi), 3) kemampuan untuk menemukan kompromi kreatif untuk mencapai solusi yang memuaskan untuk semua. Sebagai pendidik dan konselor, Wintz \& Cooper (2001) menegaskan kita perlu memiliki kompetensi dan sensitifitas budaya. Ada tiga hal yang perlu diingat untuk menyajikan sensitifitas budaya dalam bidang pelayanan klinik, diantaranya: 1) berbeda ialah berbeda, bukan mengenai benar dan salah;2) saya tidak takut untuk bertanya, ketika saya merasa tidak nyaman; 3) Ini bukan tentang saya, sehingga kita tidak bisa menggunakan ukuran kita. Oleh karena itu, dapat dipahami bahwa kompetensi budaya perlu dimiliki oleh pendidik dan juga peserta didik.

Kompetensi menurut Spencer \& Spencer dalam Palan (2007) adalah sebagai karakteristik dasar yang dimiliki oleh seorang individu yang berhubungan secara kausal dalam memenuhi kriteria yang diperlukan dalam menduduki suatu jabatan. Becker and Ulrich dalam Suparno (2005, p. 24) mengatakan bahwa kompetensi mengandung aspek-aspek pengetahuan, keterampilan (keahlian) dan kemampuan ataupun karakteristik kepribadian yang mempengaruhi kinerja. Powell (1997, p. 142) mengartikan kompetensi sebagai 1) kecakapan, kemampuan, kompetensi; dan 2) wewenang. Stephen Robbin (2007, p. 38) kompetensi adalah "kemampuan (ability) atau kapasitas seseorang untuk mengerjakan berbagai tugas dalam suatu pekerjaan, dimana kemampuan ini ditentukan oleh 2 (dua) faktor yaitu kemampuan intelektual dan kemampuan fisik.

Secara lebih rinci, Robert A. Roe (2001, p. 73) menjelaskan bahwa kompetensi dapat digambarkan sebagai kemampuan untuk melaksanakan satu tugas, peran atau tugas, kemampuan mengintegrasikan pengetahuan, keterampilanketerampilan, sikap-sikap dan nilai-nilai pribadi, dan kemampuan untuk membangun pengetahuan dan keterampilan yang didasarkan pada pengalaman 
dan pembelajaran yang dilakukan. Spencer dan Spencer dalam Palan (2007, p. 84) mengemukakan bahwa kompetensi menunjukkan karakteristik yang mendasari perilaku yang menggambarkan motif, karakteristik pribadi (ciri khas), konsep diri, nilai-nilai, pengetahuan atau keahlian yang dibawa seseorang yang berkinerja unggul (superior performer) di tempat kerja.

Spencer, McClelland, \& Spencer (1994) menyebut ada lima karakteristik yang membentuk kompetensi yakni 1). Faktor pengetahuan meliputi masalah teknis, administratif, proses kemanusiaan, dan sistem 2) Keterampilan; merujuk pada kemampuan seseorang untuk melakukan suatu kegiatan. 3) Konsep diri dan nilai-nilai; merujuk pada sikap, nilai-nilai dan citra diri seseorang, seperti kepercayaan seseorang bahwa dia bisa berhasil dalam suatu situasi. 4) Karakteristik pribadi; merujuk pada karakteristik fisik dan konsistensi tanggapan terhadap situasi atau informasi, seperti pengendalian diri dan kemampuan untuk tetap tenang dibawah tekanan. 5) Motif; merupakan emosi, hasrat, kebutuhan psikologis atau dorongan-dorongan lain yang memicu tindakan. Berdasarkan pendapat-pendapat tersebut, dapat disimpulkan bahwa kompetensi meliputi aspek kognitif, afektif dan psikomotor individu.

Sementara itu, spiritual merupakan pengalaman kesadaran individu dalam upaya menghormati keberadaan alam sejagat raya, yang dikaitkan dengan kekuatan tertinggi dalam kehidupan ini (transenden), seperti Tuhan, keabadian, puncak kebenaran tertinggi, nilai-nilai luhur, sesuatu yang bermakna, sehingga dengannya sering menginspirasi perasaan keberdayaan, harapan, kerendahan hati, dan takjub (Eaude, 2008; Tisdell, 2003; Wright, 2000). Spiritualitas ialah upaya perhatian kita terhadap makna dan tujuan hidup dalam konteks hubungan dengan alam semesta, dan atau Tuhan (Steiner, 1991; Sperry, \& Giblin; 1996, Miller \& Thoresen, 1999, George et al; 2000, Webb, Toussaint, \& Dula, 2014). Richards dan Bergin (2005) juga menyatakan karakteristik inti dari orang spiritual ialah mereka menikmati penuh kasih dan kedekatan yang tulus, dan keharmonisan.

Berdasarkan pandangan-pandangan di atas, dapat disimpulkan bahwa spiritualitas ialah suatu pengalaman kesadaran seseorang dalam menemukan makna terhadap suatu kejadian ataupan dalam kehidupannya, yang menyertakan penghayatan dan penghormatan terhadap keberadaan alam sejagat raya dan kekuatan tertinggi dalam kehidupan ini (seperti Tuhan, keabadian, puncak kebenaran tertinggi, nilai-nilai luhur), sehingga sering kali menginspirasi rasa keberdayaan, harapan, rendah hati, takjub, kasih sayang, 
ketulusan, dan keharmonisan hidup. Maka, kompetensi spiritual ialah kecakapan seseorang terkait kemampuan kognitif, afektif, dan psikomotornya dalam memaknai kehidupan.

Jika menilik pada teori psikologi transpersonal, tentu spiritualitas memiliki makna yang luas. Spiritualitas tidak sebatas pada keyakinan terhadap sesuatu kekuatan yang maha besar (yang diyakini), tetapi juga terkait dengan hubungan dengan sesama mahkluk, dan cara memaknai hidup. Oleh karena itu, spiritualitas juga memiliki pengaruh pada perilaku moral yang baik. Dengan demikian, diperlukan pemahaman yang baik mengenai makna spiritualitas dan pemahaman yang baik mengenai bagaimana pengembangan spiritualitas yang bernilai positif.

Sebagaimana besarnya manfaat spiritualitas, dapat dikembangkan secara positif pada diri manusia, maka kematangan spiritualitas seseorang menandakan kematangan dirinya. Demikian pula kematangan spiritualitas pada suatu masyarakat, bangsa atau negara. Mahasiswa sebagai salah satu generasi penerus bangsa diharapkan memiliki kecakapan yang mumpuni mengenai pengetahuan, emosional dan spiritualitas diri (sesuai masa perkembangannya).

\section{METODE}

Metode yang digunakan dalam penelitian ini ialah survei, penelitian survei merupakan penelitian yang mengumpulkan informasi dari suatu sampel dengan menanyakan melalui angket dan interview supaya nantinya menggambarkan berbagai aspek dari populasi (Faenkel \& Wallen, 1990). Studi ini ingin mengetahui profil kompetensi spiritualitas pada sekelompok mahasiswa, pada program studi Bimbingan dan Konseling Universitas Muhammadiyah Metro.

Survei yang dilakukan menggunakan intrumen angket yaitu skala kompetensi spiritualitas. yang terdiri dari tiga aspek, yakni kognitif, afektif, dan psikomotor, serta ada tujuh indikator. Indikator tersebut diantaranya; 1) Pengetahuan tentang spiritualitas dan religiusitas, 2) Pemahaman tentang keanekaragaman budaya dan nilai spiritualitas, 3) Respon terhadap keberadaan alam beserta isinya, 4) Penilaian terhadap kebenaran tertinggi (Tuhan), 5) Pengelolaan sikap diri terhadap suatu kejadian, 6) Pengalamiahan (Kebiasaan) penerapan nilai-nilai luhur terhadap diri, Tuhan, oranglain dan alam, dan 7) Kemampuan artikulasi terhadap kejadian hidup. Berdasarkan tinjauan beberapa teori, diperoleh rumusan indikator gambaran kognitif, afektif, dan psikomotor pada diri 
seseorang yang memiliki kompetensi spiritual, seperti tampak dijaikan pada Tabel 1.

Tabel 1. Definisi dan Indikator Kompetensi Spiritualitas

\begin{tabular}{|c|c|c|c|c|}
\hline Esensi & Aspek & Indikator & Sumber & $\begin{array}{l}\text { Data yang } \\
\text { dihasilkan }\end{array}$ \\
\hline \multirow{3}{*}{$\begin{array}{l}\text { Kompetensi } \\
\text { spiritual adalah } \\
\text { kemampuan } \\
\text { kognitif, afektif, } \\
\text { dan psikomotor } \\
\text { individu dalam } \\
\text { memaknai } \\
\text { kehidupan }\end{array}$} & Kognitif & $\begin{array}{l}\text { 1. Pengetahuan tentang spiritualitas dan } \\
\text { religiusitas } \\
\text { 2. Pemahaman tentang keanekaragaman } \\
\text { budaya dan nilai spiritualitas }\end{array}$ & \multirow[t]{3}{*}{$\begin{array}{l}\text { Mahasiswa } \\
\text { Bimbingan } \\
\text { dan Konseling }\end{array}$} & \multirow[t]{3}{*}{$\begin{array}{l}\text { Profil } \\
\text { Kompetensi } \\
\text { Spiritualitas }\end{array}$} \\
\hline & Afektif & $\begin{array}{l}\text { 1. Respon terhadap keberadaan alam } \\
\text { berserta isinya } \\
\text { 2. Penilaian terhadap kebenaran tertinggi } \\
\text { (Tuhan) } \\
\text { 3. Pengelolaan sikap diri terhadap suatu } \\
\text { kejadian }\end{array}$ & & \\
\hline & Psikomotor & $\begin{array}{l}\text { 1. Pengalamiahan (Kebiasaan) } \\
\text { penerapan nilai-nilai luhur terhadap } \\
\text { diri, Tuhan, oranglain dan alam } \\
\text { 2. Kemampuan artikulasi terhadap } \\
\text { kejadian hidup }\end{array}$ & & \\
\hline
\end{tabular}

Instrumen dikembangkan berdasarkan definisi dan indikator yang telah dirumuskan tersebut. Berdasarkan proses pengembangan instrumen kompetensi spiritual, diperoleh sejumlah 44 item pernyataan sebagai instumen survei yang dilakukan pada partisipan sejumlah 50 mahasiswa.

\section{METODE}

Metode penelitian kualitatif dengan pendekatan studi kasus (case study) dipilih dalam melakukan penelitian ini. Case study research sebagai bagian dari metode ini pun dimanfaatkan demi mendapatkan pengetahuan yang lebih mendalam dari para pelaku pancakaki yang diteliti di sini, dalam hal ini mereka berperan sebagai responden. Studi kasus sebagai metode yang diturunkan dari metodologi intepretif ini diharapkan bisa membantu dalam mencapai data dan pengetahuan yang dibutuhkan untuk selanjutnya diinformasikan pada khalayak umum. Karena case study menurut Berg adalah metode yang secara sistematis menggali informasi tentang seseorang, setting sosial, peristiwa, atau kelompok yang memungkinkan peneliti untuk mengerti bagaimana proses tersebut berlangsung dan berfungsi (Yin, 2003).

Pilihan mengambil studi kasus sebagai metode penelitian didasarkan pada kebutuhan-kebutuhan peneliti dalam mengumpulkan data yang akan berpengaruh pada tahap analisis data. Keterbatasan waktu penelitian yang 
tersedia menjadi salah satu faktor mengapa penelitian ini menggunakan metode studi kasus, hal tersebut berkaitan dengan sifat case study yang cenderung tidak membutuhkan waktu penelitian yang lama seperti halnya yang diperlukan oleh etnografi (Buingin 2008, p. 22). Rumusan permasalahan yang menyinggung mengenai pancakaki sebagai media pengembangan pola pewarisan nilai pada Bani Nuryayi, mengharuskan peneliti melibatkan lebih dari satu informan saja karena mekanisme cross check digunakan demi sebuah objektivitas dalam penelitian dan meminimalisasi adanya bias pada data-data yang disajikan. Untuk memperoleh data digunakan sejumlah informan pangkal yang dipilih secara purposive dari orang-orang yang memiliki hubungan geneologis dan atau memahami asal usul keberadaan keluarga besar Bani Nuryayi, dengan kiriteria Spradley (1997, p. 61), yaitu (1) adanya enkulturasi penuh; (2) keterlibatan penuh terhadap fenomena yang tengah diteliti; (3) kecukupan waktu untuk bertemu dalam menyampaikan informasi; dan (4) non analisis, yaitu informan yang mampu menggunakan bahasanya sendiri tanpa memberikan interpretasi. Teknik penelitian bertumpu pada wawancara, observasi, dan dokumentasi.

\section{HASIL DAN PEMBAHASAN}

Berdasarkan hasil survei menggunakan skala kompetensi spiritual, diperoleh keterangan bahwa skor rata-rata kompetensi spiritual kelompok sebesar 45, terdapat $24 \%$ mahasiswa yang memiliki kategori kompetensi spiritual rendah, $54 \%$ berkategori sedang, dan $22 \%$ berkategori tinggi. Sehingga dapat dimaknai bahwa secara keseluruhan, mahasiswa banyak yang memiliki kompetensi spiritual yang sedang. Sedangkan secara per aspek, keseluruhan mahasiswa memiliki tingkat tertinggi kompetensi spiritual pada aspek afektif, disusul kemudian kognitif dan psikomotor, seperti tampak pada Tabel 2. Dengan demikian, jumlah tinggi, sedang dan rendah pada setiap aspek kompetensi spiritualitas para mahasiswa bervariasi.

Tabel 2. Daftar Skor Kompetensi Spiritual Setiap Aspek

\begin{tabular}{lrrr}
\hline Kategori & Kognitif & Afektif & Psikomotor \\
\hline Tinggi & 14 & 29 & 22 \\
\hline Sedang & 27 & 16 & 16 \\
\hline Rendah & 9 & 5 & 12 \\
\hline
\end{tabular}




\section{Profil Kompetensi Spiritualitas Mahasiswa Berdasarkan Gender}

Diperoleh keterangan bahwa mahasiswa laki-laki memiliki kompetensi spiritual dengan skor rata-rata sebesar 3.96. Sedangkan mahasiswa perempuan memiliki kompetensi spiritual dengan rata-rata sebesar 4.16. Dengan demikian, skor ratarata kompetensi spiritual mahasiswa perempuan lebih tinggi dari skor rata-rata kompetensi spiritual mahasiswa laki-laki. Temuan penelitian diperoleh data pada mahasiswa bimbingan dan konseling berjenis kelamin laki-laki tingkat kompetensi spiritual yang hampir sama pada aspek afektif dan psikomotor, yakni $37 \%$ dan $36 \%$. Aspek afektif merupakan aspek yang tertinggi, menyusul kemudian aspek psikomotor. Aspek kognitif sebesar 27\%. Sedangkan, pada mahasiswi perempuan diperoleh aspek tertinggi pasa afektif dan juga psikomotor yakni sama-sama 38\%. Disusul kemudian pada aspek kognitif yakni 24\%. Dengan demikian, aspek tertinggi pada laki-laki dan perempuan sama yakni pada aspek afektif dan psikomotor.

\section{Kompetensi Spiritual Berdasarkan Profesi Orangtua}

Berdasarkan wawancara diperoleh keterangan bahwa 50 mahasiswa bimbingan dan konseling yang merupakan subjek penelitian ini terdiri dari keluarga yang berlatar belakang profesi orangtua sebagai Karyawan swasta, Petani, PNS (pegawai negeri sipil), dan wirausaha. Mahasiswa yang berlatar belakang profesi orangtua sebagai karyawan swasta diperoleh skor rata-rata kompetensi spiritual sebesar 4.33. Mahasiswa yang berlatar belakang profesi orangtua sebagai petani diperoleh skor rata-rata kompetensi spiritual sebesar 3.92. Mahasiswa yang berlatar belakang profesi orangtua sebagai PNS diperoleh skor rata-rata kompetensi spiritual sebesar 4.05. Dan, mahasiswa yang berlatar belakang profesi orangtua sebagai wirausaha diperoleh skor rata-rata kompetensi spiritual sebesar 4.24. Dengan demikian, terdapat tingkat rata-rata kompetensi spiritual yang hampir sama tingginya pada mahasiswa yang berlatar belakang profesi orangtua sebagai karyawan swasta, dan wirausaha. Disusul oleh mahasiswa yang berlatar belakang profesi orangtua sebagai PNS. Terakhir ialah mahasiswa yang berlatar belakang profesi orangtua sebagai petani.

\section{Kompetensi Spiritual Berdasarkan Latar Belakang Sekolah}

Kompetensi spiritual berdasarkan latar belakang sekolah (asal SMA) dibagi menjadi dua yakni dari sekolah yang berlatar belakang agama (sekolah islam) dan sekolah yang berlatar belakang umum (sekolah negeri atau swasta umum). Diperoleh data bahwa mahasiswa yang berasal dari sekolah agama (sekolah 
islam) memiliki tingkat spiritual dengan skor rata-rata sebesar 4.02. Mahasiswa yang berasal dari sekolah umum diperoleh tingkat spiritual dengan skor ratarata sebesar 4.13. Dapat diketahui bahwa skor rata-rata tingkat spiritual mahasiswa yang berasal dari sekolah agama cenderung sama dengan mahasiswa yang berasal dari sekolah umum. Bahkan, mahasiswa dari sekolah umum diperoleh tingkat rata-rata spiritual yang sedikit lebih tinggi.

\section{Budaya Spiritualitas Masyarakat Indonesia}

Perilaku manusia tidak dapat lepas dari budaya. Sebagaimana manusia merupakan makhluk individu dan juga sosial, manusia senantiasa beriterakasi satu sama lain, yang pada akhirnya melahirkan suatu kebudayaan. Budaya terkait dengan perilaku atau kebiasaan seseorang ataupun kelompok tertentu. Belajar budaya ialah suatu upaya mempelajari atau berbagi pengetahuan, keyakinan, tradisi, adat istiadat, aturan, seni, sejarah, cerita rakyat dan lembaga dari sekelompok orang untuk menafsirkan pengalaman dan perilaku sosial yang dihasilkan (Wintz \& Cooper, 2001). Perilaku yang dimaksud dalam budaya meliputi pola berpikir, merasa dan juga bertingkah laku, yang cenderung menetap dan membentuk suatu kebiasaan pada diri seseorang atau kelompok tertentu. Identitas budaya meliputi berbedaan berikut; objek simbol, bahasa, topik dan pola percakapan, intonasi suara, klue non verbal (gestur, ekspresi wajah, bahasa tubuh, dan ruang pribadi), konsep waktu (pesan, durasi, dan poin didalamnya), keluarga dan struktur kekerabatan (anggota dan otoritas), tradisi makan dan memasak, spiritual dan agama (Wintz \& Cooper, 2001). Dengan demikian, pola budaya seseorang atau kelompok dapat dilihat dari beberapa simbol tersebut.

Mengenai budaya spiritualitas masyarakat Indonesia, dapat kita lihat dari kecenderungan pola perilaku yang mencakup kecenderungan pola berpikir, merasa, dan bertingkah laku masyarakat Indonesia. Termasuk simbol-simbol yang digunakan dalam kehidupan mereka. Meninjau kembali makna spiritualitas ialah suatu upaya seseoang memaknai kejadian dengan melibatkan perasaan dan pikiran yang lebih luas. Luas yang dimaksud ialah dengan mengaitkannya dengan hakikat tujuan hidup, puncak kebenaran tertinggi, nilainilai luhur, ataupun kekuatan yang maha besar. Seringkali spiritualitas dikaitkan dengan religiusitas, meski keduanya merupakan suatu hal yang berbeda. Aktivitas religius akan mencapai kualitas tertinggi dengan melibatkan spiritualitas. Meski demikian, spiritualitas juga bisa dimiliki oleh orang yang tidak berreligi (Wintz \& Copper, 2001; Chuningham et al, 2009). Dalam 
konteks budaya, spiritualitas setiap individu memungkinkan memiliki tingkat dan juga bentuk yang beranekaragam. Misalnya, spiritualitas pada orang muslim berbeda dengan orang kristiani.

Masyarakat Indonesia terdiri dari budaya yang beranekaragam, dapat dipandang dari keragaman suku, agama, bahasa daerah, adat istiadat, tingkat ekonomi, tingkat pendidikan dan lainnya. Hal ini tentu mempengaruhi keanekaragaman tingkat dan bentuk spiritualitas dikalangan masyarakatnya. Meski demikian, kita dapat melihat pola kecenderungan spiritualitas masyarakat Indonesia.

Ahimsa-Putra (2011) seorang ahli antropologi mengatakan bahwa spiritualitas bangsa Indonesia masih termasuk tinggi, yang terlihat dari sila utama dari negara kita adalah "Ketuhanan Yang Maha Esa". Hal ini menunjukkan bahwa spiritualitas masih ada dalam ideologi negara kita, karena Tuhan merupakan fenomena spiritual, fenomena ghaib, meskipun kini banyak yang berpendapat bahwa sila tersebut tidak lagi banyak diikuti, karena telah diganti dengan "Keuangan Yang Maha Kuasa", namun hal ini tidak berarti bahwa bangsa Indonesia telah kehilangan spiritualitasnya. Selain itu, Ahimsa juga mengatakan spiritualitas yang tinggi dari bangsa Indonesia dapat dilihat dalam banyak hal, diantaranya; 1) pada umumnya orang Indonesia masih percaya bahkan menyukai hal-hal yang bersifat gaib, dan ingin sekali mengetahui keadan dunia ghaib tersebut. Misalnya pada beberapa acara di televisi, yang berhubungan dengan dunia mahluk ghaib; 2) Orang Indonesia juga masih banyak yang melakukan ziarah kubur, tidak dengan maksud untuk mendoakan yang telah meninggal, tetapi mendapatkan pertolongan dari roh-roh mereka; 3) Orang Indonesia juga masih banyak yang biasa melakukan "tirakat", "laku prihatin", diharapkan dengan laku prihatin ini, entah dengan berpuasa, berjaga atau melakukan "semedi" semalam suntuk, berendam di sumber air tertentu, dan sebagainya- mereka akan mendapatkan imbalan dari "alam ghaib" entah siapapun yang dimaksud, berupa kehidupan duniawi yang lebih baik, atau seperti yang telah diperoleh; dan 4) Tidak sedikit orang Indonesia yang juga masih percaya pada adanya "kekuatan-kekuatan tertentu" dalam berbagai benda yang jika dapat "disapa", diajak berkomunikasi, juga akan dapat memberikan perlindungan kepada, atau memberikan apa yang diinginkan oleh pemilik benda tersebut.

Gambaran perilaku spirituali tersebut tampaknya bagian dari sebagian potret masyarakat Indonesia, khususnya di Jawa. Mengenai hal ini memungkinkan adanya bentuk perilaku spiritualitas lainnya di daerah atau pulau lain di 
Indonesia. Indonesia merupakan negara yang memiliki keanekaragaman suku bangsa dan budaya, sebagaimana yang disebutkan oleh Furnifall bahwa di masa penjajahan belanda, masyarakat Indonesia merupakan masyarakat yang memiliki perbedaan-perbedaan agama, ras, suku bangsa, adat, dan kedaerahan yang antara elemen satu dan elemen lainnya dalam kehidupan sehari-hari tidak ada pembauran dalam satu kesatuan politik. Setiadi dan Kolip (2013) juga menjelaskan masyarakat Indonesia disebut sebagai masyarakat tropis, yang daerah ini terdapat kelompok masyarakat yang berkuasa dan masyarakat yang dikuasai yang memiliki perbedaan ras.

Sebagaimana spiritual idealnya memiliki kontribusi pada perilaku moral yang positif. Dalam hal ini, Ahimsa-Putra (2011) mengaitkan keadaan spiritualitas bangsa Indonesia dengan perilaku moralnya, Banyak pihak yang menilai, termasuk orang Indonesia sendiri, bahwa moralitas bangsa ini sekarang sedang merosot terus. Indikatornya; Ketidakdisiplinan yang terjadi di mana-mana. Ini terjadi di semua lapisan masyarakat, dari yang paling atas hingga yang paling bawah. Mulai dari para wakil rakyat yang banyak membolos, pegawai negeri yang datang terlambat ke kantor, atau datang tepat waktu kemudian pergi lagi, absen yang dititipkan pada teman, dosen yang banyak "mroyek", pelajar yang malas belajar, sampai lalu-lintas yang semrawut, semuanya merupakan gejala yang sangat umum di Indonesia. Meskipun hal-hal tersebut telah banyak dikeluhkan, namun tidak banyak perubahan yang dirasakan. Bentuk perilaku moral yang merosot pun terlihat dari fenomena ketidakjujuran (korupsi, kolusi, dan nepotisme), kerusuhan diberbagai tempat, dan tindak kejahatan. Mengenai masalah ini, Ahimsa pun memaparkan beberapa penyebab mengapa kemerotan moral itu terjadi diantaranya karena; 1) perubahan tidak sistemik (kesenjangan budaya), 2) difusi kebudayaan yang cepat (globalisasi), 3) perubahan dan kesenjangan spiritual, 4) perubahan tipe budaya masyarakat Indonesia.

Berdasarkan hasil survei pada 50 mahasiswa bimbingan dan konseling, diketahui bahwa terdapat $22 \%$ mahasiswa yang memiliki kompetensi spiritual yang tinggi, $54 \%$ sedang, dan $24 \%$ rendah. Ini menunjukan bahwa sebagian besar pada kelompok mahasiswa tersebut memiliki kompetensi spiritual yang tergolong sedang. Aspek tertinggi pada afektif, disusul kemudian kognitif dan terakhir psikomotor. Jika dikaitkan dengan kajian yang dipaparkan oleh Ahimsa, dapat dipahami bahwa ada kesenjangan antara kompetensi afektif dengan psikomotor pada diri mahasiswa, hal ini bisa menunjukan bahwa spiritualitas sebagian masyarakat kita pada aspek afektif tergolong baik, namun 
dalam aspek kognitif hingga psikomotor belum berjalan dengan baik. Hal ini tampaknya yang mempengaruhi protret kemerosotan moral masyarakat kita.

Berdasarkan tinjauan teori, perkembangan spiritualitas terkait dengan perkembangan nilai-nilai, dimana perkembangan nilai seseorang dipengaruhi oleh lingkungan (budaya, keluarga, masyarakat, sekolah), situasi dan kondisi, pengalaman emosional, keadaan fisik dan juga genetika. Tampak faktor internal dan eksternal individu begitu mempengaruhi perkembangan spiritualitasnya. Oleh karena itu selain pengembangan dari sisi kesadaran individu, diperlukan juga pengembangan dari sisi lingkungan. Sisi lingkungan meliputi keluarga, lembaga pendidikan, dan pemerintah.

Perkembangan spiritual pada 50 mahasiswa tersebut menunjukan banyaknya mahasiswa yang memiliki skor tinggi pada aspek afektif, selanjutnya banyak mahasiswa memperoleh skor tinggi pada aspek psikomotor, dan hanya sedikit mahasiswa yang memperoleh skor tinggi pada aspek kognitif. Hal ini menunjukan bahwa perkembangan spiritual mahasiswa masih cenderung pada ranah perasaan namun belum dibarengi oleh pemahaman dan tindakan nyata.

Aspek kognitif meliputi; 1) Pengetahuan tentang spiritualitas dan religiusitas, dan 2) Pemahaman tentang keanekaragaman budaya dan nilai spiritualitas. Sepertinya, sebagian besar mahasiswa belum memiliki pemahaman yang memadai mengani hakikat spiritual, terutama perbedaan spiritual dengan religiusitas dan pemahaman tentang keanekaragaman budaya dan spiritualitas. Bisa jadi hal tersebut turut mendorong tindakan spiritualitas yang dapat terlihat dari aspek psikomotor.

Terkait dengan perilaku moral, rendahnya aspek psikomotor pada kompetensi spiritual dapat mengindikasikan bahwa bisa dipahami jika aktivitas budaya spiritual sebagian masyarakat Indonesia tidak berkorelasi pada perilaku moral yang nyata. Ahimsa (2011) juga mengatakan akar kemerosotan moral masyarakat Indonesia ialah karena kesenjangan budaya. Oleh karena itu Ahimsa merekomendasikan solusi untuk mengatasi kemerotan moral tersebut ialah dengan melakukan adaptasi yang tepat dan cepat terhadap perubahan-perubahan teknologi, institusi, dan pengetahuan yang berlangsung begitu cepat masuk dalam masyarakat Indonesia.

Ahimsa (2011) juga menyebutkan bahwa daptasi yang cepat dan tepat tersebut akan dapat terwujud apabila proses tersebut didasarkan pada suatu bentuk spiritualitas yang tepat juga, yakni: tauhid atau pengutamaan Sang Maha 
Pencipta lebih dari yang lain-lain, yang ada di muka bumi. Tentu saja solusi "tauhid" ini didasarkan pada asumsi-asumsi dasar tertentu, diantaranya; 1) masyarakat Indonesia menganut pandangan bahwa Tuhan, Allah itu ada, dan Maha Esa. Tuhan tersebut juga Maha Pencipta, Maha Bijaksana, Maha Kuasa, Maha dalam

segala yang bersifat baik. Tanpa anggapan akan ada-nya Tuhan Yang Maha Pencipta ini, yang berkuasa terhadap kehidupan manusia, solusi spiritual berupa "ketauhidan" tidak akan ada artinya; 2) Tuhan Yang Maha Pencipta ini Tidak dapat diduakan dengan Yang lain-lain. Tindakan penduaan atau menyekutukan Tuhan bertentangan dengan pandangan keMaha-an

Tuhan itu sendiri. Oleh karena itu, unsur-unsur spiritual lainnya tidak perlu diperhatikan lagi. Perhatian utama cukup dan harus diberikan pada sumber dari segala spiritualitas, yaitu Tuhan atau Allah tiu sendiri; 3) Ketauhidan yang kuat akan menghasilkan ketunggalan spiritualitas, yaitu spiritualitas yang memfokus pada sumber spiritualitas yang satu, Sehingga enerji manusia dapat dipusatkan sepenuhnya pada upaya untuk memuliakan "Sang Spirit", "Roh dari segala Roh". Hanya dengan tauhid yang kokoh inilah proses adaptasi yang cepat dan tepat, yang membawa selamat, di dunia dan di akhirat, dapat terwujud. Oleh karena itu, untuk menguatkan spiritualitas dan juga moral masyarakat Indonesia diperlukan penguatan spiritual yang bersumber pada Tuhan Yang Maha Esa.

\section{Upaya Pengembangan Spiritualitas}

Sebagaimana kepribadian, spiritualitas pada seseorang juga dapat berkembang. Wintz \& Cooper (2001) menyebutkan beberapa pemicu yang dapat menyebabkan fokus spiritual atau krisis dalam kehidupan seseorang mencakup; 1) Faktor fisik (seperti penyakit, kecelakaan, operasi, kurang tidur atau makanan, atau pengalaman melahirkan); 2) Pengalaman emosional atau transisi (kelahiran, membuat komitmen seperti hubungan yang signifikan, pernikahan, atau menjadi anggota dari sebuah komunitas iman, perubahan gaya hidup, bergerak, stres, atau kehilangan pekerjaan, pernikahan, persahabatan atau kematian); 3) Pengalaman dekat kematian (apakah itu sendiri atau yang orang yang dicintai); dan 5) Praktik Spiritual (meditasi, doa, ritual, atau kehadiran di gereja). Pendapat tersebut banyak menekankan pada faktor internal pribadi seseorang, disamping faktor eksternal. Menurut teori, kepribadian juga dipengaruhi oleh faktor genetik, lingkungan, dan pengalaman (Yusuf \& Nurihsan, 2009). Profil kompetensi spiritual mahasiswa tersebut bisa 
dipengaruhi oleh faktor genetik yang diturunkan oleh orangtua, lingkungan ia hidup dan pengalaman yang pernah ia lalui. Disebutkan pula bahwa pengalaman emosional dan spiritual mempengaruhi perkembangan spiritual juga. Sedangkan faktor lingkungan meliputi lingkungan keluarga, tempat tinggal, sekolah hingga kebijakan pemerintahan. Dengan demikian, dapat dipahami adanya bentuk spiritualitas yang hampir sama antar individu disuatu daerah atau negara tertentu.

Selain profil spiritual secara umum, tulisan ini juga menyajikan profil kompetensi spiritual berdasarkan gender, profesi orang tua dan asal sekolah. Gender terdiri dari laki-laki dan perempuan, Lever (Setiadi \& Kolip, 2013) menyebutkan beberapa ciri perbedaan kepribadian perempuan dan laki-laki diantaranya: 1) anak laki-laki lebih banyak memperoleh kesempatan bermain di luar rumah dan bermain lebih lama ketimbang anak perempuan, 2) permainan anak laki-laki lebih bersifat kompettitif dan kontruktif karena anak laki-laki lebih tekun dan efektif dari anak perempuan, dan 3) permainan anak perempuan lebih banyak bersifat kooperatif dan lebih banyak berada di dalam ruangan.

Maccoby (Setiadi \& Kolip, 2013) mengatakan perbedaan perilaku bagi perempuan dan laki-laki sebenarnya timbul bukan karena faktor bawaan sejak lahir tetapi lebih disebabkan karena sosial-budaya masyarakat yang membedakan perlakuan terhadap perempuan dan laki-laki sejak awal masa perkembangan (masa kanak-kanak). Setiadi \& Kolip (2013) juga berpendapat bahwa di Indonesia telah mempunyai basis legal yang menjamin hak dan kesempatan bagi laki-laki dan perempuan, akan tetapi masih banyak kendala budaya dan struktural yang membuat perempuan masih menghadapi kesulitan, khususnya dalam hal partisipasinya dalam mengambil keputusan dan kekuasan. Hal ini lebih dikarenakan lingkungan dan struktur budaya tidak banyak mendukung terciptanya partisipasi penuh dari perempuan dalam dunia politik maupun dalam mengambil keputusan. Disebutkan juga dalam beberapa teori bahwa perempuan cenderung lebih banyak menggunakan perasaan, sedangkan laki-laki lebih cenderung menggunakan logika. Jika demikian, diperkirakan perempuan lebih tinggi tingkat spiritualitasnya. Namun, berdasarkan hasil suvey diketahui bahwa skor rata-rata kompetensi spiritual mahasiswa perempuan hanya sadikit lebih tinggi dari laki-laki. Dalam arti hampir sama. Berdasarkan hasil survei dapat disimpulkan bahwa perbedaan gender tidak terlalu berpengaruh pada tingkat spiritual seseorang. 
Pertimbangan lainnya ialah bahwa spiritualitas dipengaruhi pula dari lingkungan keluarga, dengan demikian pola asuh orangtua bisa mempengaruhi kepribadian termasuk spiritualitas seseorang. Pola asuh seseorang terhadap anaknya bisa dipengaruhi oleh cara berpikirnya, maka bisa diperkirakan profesi seseorang pun bisa mempengaruhi perilaku dan pola asuh terhadap anaknya. Sebagaimana, Wintz \& Copper (2001) juga mengatakan bahwa budaya yang diusung sangat mempegaruhi sopan santun, keyakinan, nilai dan tingkah laku.

Keluarga dapat mengajarkan tentang keyakinan dan memperlakukan orangorang yang berasal dari budaya yang berbeda. Dapat dipahami, sering kali masyarakat pada daerah satu dengan daerah lain memiliki aktivitas, tingkat maupun nilai spiritualitas yang berbeda. Diketahui bahwa skor rata-rata tingkat spiritualitas yang tertinggi pada 50 mahasiswa tersebut ialah mahasiswa yag berasal dari orangtua yang berprofesi kariayawan swasta, disusul kemudian dari orangtua yang berprofesi wirausaha, PNS, dan terakhir petani. Nilai rata-rata skor kompetensi spiritual mahasiswa dari orangtua yang berprofesi sebagai pegawai swasata dan wirausaha hanya sedikit perbedaan. Itu artinya hampir sama. Jika dianalisis, ada persamaan antara pekerja sebagai karyawan swasta dan wirausaha diantaranya; mereka lebih bebas dan fleksibel mengembangkan diri dari pada PNS, penghasilan yang mungkin tidak tetap pada setiap bulannya memungkinkan mereka untuk terus berupaya berinovasi, dan penerimaan lingkungan atau masyarakat begitu mereka harapkan yang mempengaruhi pendapatan mereka. Sedangkan PNS, cenderung lebih stagnan dalam bekerja, cukup nyaman dengan terjaminnya pendapatan tiap bulan, pengembangan diri tidak terlalu berpengaruh pada pendapatan, terikat dengan kebijakan pemerintah, dan tidak terikat dengan musim ataupun sikap masyarakat. Sedangkan petani, cenderung terikat dengan musim, keadaan alam, kebijakan harga dari pemerintah, dan merak tidak mudah beralih usaha sebagaimana wirausaha.

Spiritualitas juga dipengaruhi oleh lingkungan sekolah. Asal sekolah berbasis agama memungkinkan muatan aktivitas religius yang berdekatan dengan pengalaman spiritual lebih banyak dibanding sekolah umum (yang tidak berbasis agama). Maka, dapat diprediksi bahwa mahasiswa yang berasal dari sekolah SMA yang berbasis agama akan lebih tinggi spiritualitasnya daripada mahasiswa yang berasal dari sekolah umum. Akan tetapi, berdasarkan hasil survei diketahui bahwa skor rata-rata kompetensi spiritual mahasiswa yang berasal dari sekolah umum sedikit lebih tinggi (cenderung sama) dengan skor 
rata-rata kompetensi spiritual pada mahasiswa yang berasal dari sekolah umum. Ini artinya tidak ada perbedaan tingkat spiritualitas antara mahasiswa yang berasal dari SMA yang berbasis agama dengan SMA umum.

Wintz \& Copper (2001) menyebutkan bahwa spiritual itu: dapat dimiliki oleh orang yang beragama maupun yang tidak beragama; Mengekspresikan sumber makna, keyakinan keterhubungan dan haapan; Keyakinan, nilai dan situasi bermain penting dalam pembentukan spiritualitas seseorang; dan Spiritualitas masing-masing orang ialah penting. Cuningham (2011) juga menyebutkan bahwa spiritual bersifat bebas daripada religiusitas. Oleh karena itu, banyaknya aktivitas religius belum tentu menjamin spiritualitas yang tinggi. Zhou et al (2010) juga mengatakan bahwa spiritualitas, seperti udara atau napas, sesuatu yang mengisi seseorang, sesuatu yang menghubungkan orang-orang dengan suasana sekitarnya, sesuatu dimana tubuh manusia bergantung sebagai upaya memelihara dan memperoleh rezeki, tetapi hubungan ini antara spiritual dan materi tidak selalu ditekankan dalam beberapa tradisi agama.

Berdasarkan hasil survei tersebut menunjukan bahwa budaya seseorang (bisa itu mengenai pola asuh, gender, pengalaman pendidikan, atau lainnya) bisa mempengaruhi persamaan atau perbedaan tingkat spiritualitas seseorang. Constantine et al (2002) mengatakan dalam memahami kompetensi (spiritualitas) didasarkan dari literasi multikultur, dimana kompetensi multikultur merupakan perilaku/keyakinan, pengetahuan, dan keterampilan dalam bekerja dengan individu dari berbegai macam variasi kelompok budaya. Zhou et al (2010) mengemukakan semua tradisi spiritual yang beragam mengakui fakta bahwa orang hidup dan bernapas dengan disposisi keyakinan lama (paradoks) yang berakar dalam ketakutan dan harapan, kecemasan dan kasih sayang, integrasi dan pemisahan. Keanekaragaman budaya di Indonesia bisa mengakibatkan kecenderungan perbedaan dan juga persamaan tingkat dan bentuk spiritualitas diantara pada masyarakatnya.

Mengingat manfaat spiritualitas bagi pengembangan pribadi seseorang, mendorong pentingnya pengembangan spiritualitas pada diri seseorang bahkan masyarakat. Berdasarkan tinjauan teori spiritualitas dapat disimpulkan bahwa spiritualitas bisa menjadi potensi terhadap kesehatan jiwa, profesionalisme, hidup lebih teratur dan sehat, cinta kasih, keharmonisan, dan sikap-sikap terpuji (moral baik). Ron Best (2000) menyebutkan ada tiga cara untuk membantu pengembangan spiritualitas siswa, yaitu pengembangan kurikulum, pengembangan budaya, dan pendekatan kolaboratif guru. Sedangkan Eaude 
(2008) menyebutkan ada beberapa hal yang harus dilakukan guru untuk mengembangkan spiritualitas siswa diantaranya; pendekatan spiritualitas di kelas, integrasi spiritualitas dalam kurikulum, mendorong budaya lingkungan yang mendorong spiritualitas, dan pengenbangan profesionalisasi guru melalui spiritualitas.

Bimbingan dan konseling merupakan bagian dari pendidikan yang memiliki tujuan untuk mempersiapkan para generasi muda (peserta didik) menjadi pribadi yang berkualitas, bermartabad, dan berke-Tuhanan yang Maha Esa (sebagaimana tujuan pendidikan nasional). Dengan demikian, diperlukan pendekatan-pendekatan dalam pendidikan dan juga bimbingan dan konseling untuk mendukung terwujudnya cita-cita tersebut. Spiritualitas merupakan sebuah kekuatan dalam diri seseorang yang bisa menjadi potensi positif untuk pengembangan diri. Alangkah baiknya bila kekuatan spiritualitas dalam dimanfaatkan dan dioptimalkan dalam proses pendidikan dan juga bimbingan dan konseling.

\section{SIMPULAN}

Sebagian besar mahasiswa memiliki kompetensi spiritual yang sedang, setengahnya lagi berkompetensi tinggi dan rendah. Banyak mahasiswa memiliki skor tertinggi pada aspek afektif, sedangkan pada aspek psikomotor lebih sedikit dan aspek kognitif begitu rendah. Artinya pengetahuan dan pemahaman mahasiswa mengenai spiritualitas masih tergolong rendah disusul kemudian tindakannya (psikomotor).

Berdasarkan profil di atas dan mengingat potensi spiritualitas bagi pengembangan karakter mahasiswa, maka diperlukan pengembangan lebih lanjut mengenai spiritualitas mahasiswa atau juga masyarakat terutama melalui pendidikan serta bimbingan dan konseling. Keanekarakaman budaya di Indonesia mendorong adanya keanekaragaman tingkat dan bentuk spiritualitas diantara masyarakatnya, maka diperlukan pendekatan spiritualitas yang bernuansa multikultur.

Pengembangan praktik dan riset di bidang bimbingan dan konseling serta pendidikan yang dapat memanfaatkan potensi spiritualitas bagi pengembangan karakter para mahasiswa penting dilakukan. Juga diperlukan pengembangan program untuk meningkatkan kompetensi spiritualitas bagi mahasiswa atau masyarakat di Indonesia, terutama pada aspek kognitif, dan psikomotor. 


\section{REFERENSI}

Ahimsa-Putra, H. S. (2011). Paradigma profetik, mungkinkah? perlukah?. Makalah disampaikan dalam "Sarasehan Profetik 2011", diselenggarakan oleh Sekolah Pascasarjana UGM di Yogyakarta, 10 Februari 2011.

Anderson, K. R., \& Reese, R. D. (1999). Spiritual Mentoring: A Guide for Seeking \& Giving Direction. Intervarsity Press.

Best, R. (Ed.). (2000). Education for spiritual, moral, social and cultural development. London: A\&C Black.

Constantine, M. G., Wilton, L., Gainor, K. A., \& Lewis, E. L. (2002). Religious participation, spirituality, and coping among African American college students. Journal of College Student Development, 43(5), 605.

Cunningham, P. F. (2011). Bridging Psychological Science and Transpersonal Spirit: A Primer of Transpersonal Psychology. Nashua, NH: Rivier University.

Davis, K. M., Lambie, G. W., \& Ieva, K. P. (2011). Influence of familial spirituality: Implications for school counseling professionals. Counseling and Values, 55(2), 199-209.

Denton, D., \& Ashton, W. (Eds.). (2004). Spirituality, action \& pedagogy: Teaching from the heart. New York, NY: Peter Lang.

Dobmeier, R. A., \& Reiner, S. M. (2012). Spirituality in the counselor education curriculum: A national survey of student perceptions. Counseling and Values, 57(1), 47-65. doi: 10.1002/j.2161-007X.2012.00008.x

Eaude, T (2004). Values Education: Developing positive attitudes. Birmingham: National Primary Trust.

Eaude, T. (2008). Children's spiritual, moral, social and cultural development: Primary and early years. Britanian: Learning Matters.

Eagleton, T (2000). The idea of culture. Oxford: Blackwell

Elder, G. H. (1998). The life course as developmental theory. Child Development, 69(1), 1-12. doi: IO.1111/j .1467-8624.1998. tb06128.x

Fox, M. (1999). A spirituality named compassion: uniting mystical awareness with social justice. Vermont: Inner Traditions/Bear \& Co.

Fredrickson, L. M., \& Anderson, D. H. (1999). A qualitative exploration of the wilderness experience as a source of spiritual inspiration. Journal of environmental psychology, 19(1), 21-39. 
George, L. K., Larson, D. B., Koenig, H. G., \& McCullough, M. E. (2000). Spirituality and health: What we know, what we need to know. Journal of Social and Clinical Psychology, 19, 102-116.

Grof, S. (2000). Psychology of the future: Lessons from modern consciousness research. Albany, NY: State University of New York Press.

Hay \& Nye, R (1998). The Spirit of the Child. London: Fount.

Hay, D., Reich, K. H., \& Utsch, M. (2006). Spiritual development: Intersections and divergence with religious development. In E. C. Roehlkepartain, P. E., King, L. Wagener, \& P. L. Benson (Eds.), The handbook of spiritual Development in Childhood and Adolescence (pp. 46-59). Thousand Oaks, CA: Sage.

Hidayat, A. (2016). Holistic vision: Integrative approach in guidance and counseling service. GUIDENA: Jurnal Ilmu Pendidikan, Psikologi, Bimbingan dan Konseling, 6(1), 1-10.

Illes, K., \& Zsolnai, L. (2015). The role of spirituality in business education. Society and Business Review, 10(1), 67.

Koentjaraningrat. (2009). Pengantar Ilmu Antrologi. Rineka Cipta: Jakarta.

Lajoie, D. H., \& Shapiro, S. I. (1992). Definitions of transpersonal psychology: The first twenty-three years. The Journal of Transpersonal Psychology, 24(1), 79-98.

Lines, D. (2006). Spirituality in counselling and psychotherapy. Sage.

Miller, G. (2002). Incorporating spirituality in counseling and psychotherapy: Theory and technique. Hoboken, NJ: Wiley.

Miller, W. R., \& Thoresen, C. E. (1999). Spirituality and health. In W. R. Miller (Ed.), Integrating Spirituality into Treatment: Resources for Practitioners (pp. 3-18). Washington, DC: American Psychological Association.

Meuwese, R., Crone, E. A., Rooij, M., \& Güroğlu, B. (2015). Development of equity preferences in boys and girls across adolescence. Child development, 86(1), 145-158. doi: 10.1111/cdev.12290

Novitasari, Y., \& Nur, M. (2017). Bimbingan dan konseling belajar (akademik) dalam perspektif Islam. Indonesian Journal of Educational Counseling, 1(1), 53-78.

Ofsted. (2004) Promoting and evaluating pupils' spiritual, moral, social and cultural development. UK: Office for Standars in Education.

Palmer, P. (2004). A hidden wholeness: The journey toward an undivided life. San Francisco: Jossey-Bass. 
Pargament, K. I. (1996). Religious methods of coping: Resources for the conservation and transformation of significance. In E. P. Shafranske (Ed.), Religion and the clinical practice of psychology (pp. 215-239). Washington, DC: American Psychological Association.

Propst, L. R. (1980). The comparative efficacy of religious and nonreligious imagery for the treatment of mild depression in religious individuals. Cognitive Therapy and Research, 4(2), 167-178.

Maslow, A. H. (1962). Lessons from the Peak-Experiences. Journal of Humanistic Psychology, 2(1), 9-18.

Miller, G. (2013). Spirituality in counseling and psychotherapy. Canada: Jhon Wiley \& Son.

Miller, W. R., \& Thoresen, C. E. (1999). Spirituality and health. In Miller, William R. (Ed). Integrating spirituality into treatment: Resources for practitioners (pp. 3-18). Washington, DC, US: American Psychological Association

Richards, P. S., \& Bergin, A. E. (1997). A spiritual strategy for counseling and psychotherapy. Washington, DC: American Psychological Association.

Richards, P. S., \& Bergin, A. E. (Eds.). (2000). Handbook of psychotherapy and religious diversity. Washington, DC: American Psychological Association.

Richards, P. S., \& Bergin, A. E. (2005). A spiritual strategy for counseling and psychotherapy (2nd ed.). Washington, DC: American Psychological Association.

Setiadi, E. M., \& Kolip, U. (2013). Pengantar Sosiologi. Jakarta: Kencana.

Shorrock, A. (2008). The transpersonal in psychology, psychotherapy and counselling. London: Palgrave Macmillan.

Sperry, L., \& Giblin, P. (1996). Marital and family therapy with religious persons. In E. P. Shafranske (Ed.), Religion and the clinical practice of psychology (pp. 511-532). Washington, DC: American Psychological Association.

Selvam, S. G. (2013). Towards religious-spirituality: a multidimensional matrix of religion and spirituality. Journal for the Study of Religions and Ideologies, 12(36), 129-152.

Spencer, L. M., McClelland, D. C., \& Spencer, S. M. (1994). Competency assessment methods: History and state of the art. Hay/McBer Research Press. 
Steiner, R. (1991). The SPiritual Guidance Of The Individual And Humanity. New York: Anthroposophic Press.

Thoreau, H. D., \& Ingman, B. C. (2004). Spirituality and Experiential Education, 13, 143-158.

Tisdell, E. J. (2003). Exploring spirituality and culture in adult and higher education. San Francisco: Jhon Wiley \& Son, Inc.

Webb, J. R., Toussaint, L., \& Dula, C. S. (2014). Ritualistic, theistic, and existential spirituality: Initial psychometric qualities of the RiTE measure of spirituality. Journal of religion and health, 53(4), 972-985. doi: 10.1007/s 10943-013-9697-y

Wintz, S., \& Cooper, E. (2001). A quick guide to cultures and spiritual traditions. Yuma, AZ: Catholic Healthcare West Arizona and Yuma Regional Medical Center.

Wright, A. (2000). Spirituality and education. UK: Taylor \& Francis.

Yusuf, S., \& Nurihsan, J. (2008). Teori kepribadian. Bandung: Remaja Rosdakarya.

Zhou, G., Stoltzfus, J.C., Houldin, A.D., Parks, S.M., \& Swan, B.A. (2010). Knowledge, attitudes, and practice behaviors of oncology advanced practice nurses regarding advanced care planning for patients with cancer [Online exclusive]. Oncology Nursing Forum, 37, E400-E410. doi:10.1188/10.ONF.E400-E410 